UDC: $\mathbf{3 5 1}$

DOI: https://doi.org/10.32689/2617-

2224-2019-4(19)-117-128

Kifriak Oleksandr Nikolaevich,

graduate student of the Interregional Academy of Personnel Management, deputy head, Office of the State Architectural and Construction Inspectorate in Chernivtsi region, 58001, Chernivtsi, Str. P. Celana, 11, tel.: +38 (050)675 22 41, e-mail: sankif@ukr.net

ORCID: 0000-0001-9724-6557

Кіфряк Олександр Миколайович, аспірант Міжрегіональної Академії управління персоналом, заступник начальника, Управління Державної архітектурно-будівельної інспекції у Чернівецькій області, 58001, м. Чернівиі, вул. П. Целана, 11, тел.: +38 (050) 67522 41, e-mail: sankif@ukr.net

ORCID: 0000-0001-9724-6557

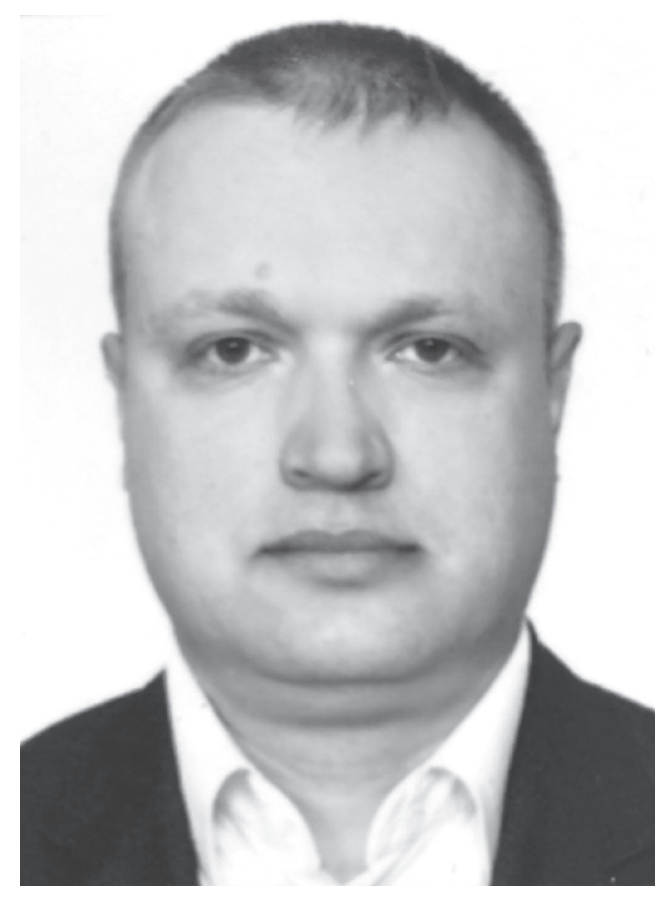

Кифряк Александр Николаевич, аспирант Межрегиональной Академии управления персоналом, заместитель начальника, Управления Государственной архитектурно-строительной инспекции в Черновицкой области, 58001, г. Черновиы, ул. П. Целана, 11, тел.: +38 (050) 67522 41, e-mail: sankif@ukr.net

ORCID: 0000-0001-9724-6557

\title{
EVOLUTION OF THE DOCRINAL AND NORMATIVE APPROACHES OF THE EUROPEAN UNION TO THE PHENOMENON OF TRANSPARENCY IN PUBLIC ADMINISTRATION
}

\begin{abstract}
The article is devoted to the study of the provisions on transparency in the works of scientists of the European Union. Highlights the main mechanisms for ensuring transparency in the European Union. The concept of transparency is considered as an integral element of the European "acquis communautaire" system. The legal grounds for introducing the concept of transparency into the system of government of European states are investigated. The consequences of the conclusion of the Association Agreement with the EU by Ukraine as a prerequisite for ensuring the transparency of the functioning of public authorities are studied. The first system analysis of the Agreement was made from the point of view of its initiatives in the field of transparency. The legal assessment of the con-
\end{abstract}


cept of transparency is given in terms of its practical implementation in Ukrainian society. Opened their own recommendations on possible mechanisms to ensure the transparency of public institutions based on international experience. It has been determined that openness and transparency of government bodies are integral characteristics of the exercise of state power based on real democracy. It has been established that transparency in the activities of government bodies can not only level out the tension in society associated with illegal actions of public authorities, more fully and efficiently take into account the needs of various social groups, but also significantly improve the efficiency of public institutions. The development of the European administrative space is revealed through the prism of introducing the concept of good governance and good administration as the basic manifestations of the "people-centeredness" ideology as a European tradition of administrative law understanding.

Keywords: transparency, European Union, European Union law, acquis communautaire, European administrative space, Association Agreement with the EU, good governance, good administration, human centricity, legal thinking, European doctrine.

\section{ЕВОЛЮЦІЯ ДОКТРИНАЛЬНИХ ТА НОРМАТИВНИХ ПІДХОДІВ ЄВРОПЕЙСЬКОГО СОЮЗУ ДО ФЕНОМЕНУ ПРОЗОРОСТІ В ДЕРЖАВНОМУ УПРАВЛІННІ}

Анотація. Досліджено положення про прозорість у працях науковців країн Європейського Союзу. Висвітлено основні механізми забезпечення прозорості в країнах Європейського Союзу. Розглянуто концепцію прозорості як складову європейської системи "acquis communautaire”. Досліджено правові підстави запровадження концепції прозорості у систему державного правління європейських держав. Окреслено наслідки укладення Україною Угоди про асоціацію з СС як передумови для забезпечення прозорості функціонування інститутів публічної влади. Зроблено перший системний аналіз Угоди з точки зору наявних в ній ініціатив у сфері прозорості. Надано правову оцінку концепції прозорості з точки зору її практичної реалізації в українському суспільстві. Розкрито власні рекомендації щодо можливих механізмів забезпечення прозорості діяльності публічних інституцій на основі зарубіжного досвіду. Визначено, що відкритість і прозорість органів державного управління є невід'ємними характеристиками здійснення державної влади на засадах реальної демократії. Встановлено, що прозорість у діяльності органів державного управління здатна не тільки нівелювати напруження в суспільстві, пов'язане з неправомірними діями органів публічної влади, найповніше та якісніше враховувати потреби різних соціальних груп, а й суттєво підвищити ефективність діяльності публічних інституцій. Розкрито розвиток Європейського адміністративного простору через призму впровадження концепції належного врядування (good governance) та належного управління (good administration) як базових виявів ідеології “людиноцентричності” як європейської традиції адміністративного праворозуміння. 
Ключові слова: прозорість, Євросоюз, право Європейського Союзу, асquis communautaire, Європейський адміністративний простір, Угода про асоціацію з $\mathrm{CC}$, good governance, good administration, людиноцентричність, праворозуміння, європейська доктрина.

\section{ЭВОЛЮЦИЯ ДОКТРИНАЛЬНЫХ И НОРМАТИВНЫХ ПОДХОДОВ ЕВРОПЕЙСКОГО СОЮЗА К ФЕНОМЕНУ ПРОЗРАЧНОСТИ В ГОСУДАРСТВЕННОМ УПРАВЛЕНИИ}

Аннотация. Исследованы положения о прозрачности в трудах ученых стран Европейского Союза. Освещены основные механизмы обеспечения прозрачности в странах Европейского Союза. Рассмотрена концепция прозрачности как составной элемент европейской системы "acquis communautaire”. Очерчены правовые основания введения концепции прозрачности в систему государственного правления европейских государств. Исследованы последствия заключения Украиной Соглашения об ассоциации с ЕС как предпосылки для обеспечения прозрачности функционирования институтов публичной власти. Сделан первый системный анализ Соглашения с точки зрения имеющихся в ней инициатив в сфере прозрачности. Дана правовая оценка концепции прозрачности с точки зрения ее практической реализации в украинском обществе. Раскрыто собственные рекомендации относительно возможных механизмов обеспечения прозрачности деятельности публичных институтов на основе зарубежного опыта. Определено, что открытость и прозрачность органов государственного управления являются неотъемлемыми характеристиками осуществления государственной власти на основе реальной демократии. Установлено, что прозрачность в деятельности органов государственного управления способна не только нивелировать напряжение в обществе, связанное с неправомерными действиями органов публичной власти, наиболее полно и качественно учитывать потребности различных социальных групп, но и существенно повысить эффективность деятельности публичных институтов. Раскрыто развитие Европейского административного пространства через призму внедрения концепции надлежащего управления (good governance) и (good administration) как базовых проявлений идеологии “человекоцентричности” как европейской традиции административного правопонимания.

Ключевые слова: прозрачность, Евросоюз, право Европейского Союза, acquis communautaire, Европейский административное пространство, Соглашение об ассоциации с ЕC, good governance, good administration, человекоцентричность, правопонимания, европейская доктрина.

Problem statement. The basic principles and values of public administration and local self - government began to be formed in the democratic countries of Europe long before the emergence of the European Union, but 
they were defined as the General European principles of public administration, when the process of unification of States into the European Union (hereinafter-the EU) started in Europe.

The idea of Europe as a single legal space is designed for a long historical perspective. In this regard, the further development of the integration movement provides for the development and codification of European legal norms and principles as outstanding beginnings of the integration process.

Degree of scientific development. It should be noted that the growing popularity of the term "transparency" in national and international instruments has generated considerable interest in Western legal doctrine prior to the formulation of the definition, legal nature and content of the concept of transparency. This issue was covered in special studies of such scientists as S. Bijsterveld, V. Deckmyn, G. Hernândez, V. Karageorgou, C. Monda, A. Peters, J. Rideau, C.-S. zoellner's. Special attention should be paid to a comprehensive study of A. Bianchi and A. Peters "Transparency in international law". The problem of transparency of public institutions was investigated by such foreign scientists as A. Asaul, Yu. Vinislav, A. Berkuta, I. Mazur, G. Archibald, F. Behluli, K. Grei, E. Larson, M. Fujita, N. Temple, F. Fabozzi etc.

At the same time, as of now, domestic scientists have not evaluated the views of the above foreign scientists and have not outlined the epistemological significance of the concept of transparency in their doctrinal developments.

The purpose of this article is to study the evolution of regulatory ap- proaches to the definition and consolidation of the concept of transparency at the level of European Union law and to determine the institutional framework for the implementation of the principle of transparency in the activities of public institutions of the European Union.

\section{Presentation of the main mate-} rial. Central and Eastern European countries wishing to join the European Union should undertake public administration reforms to meet the Copenhagen and Madrid criteria for membership in the European Union [1].

The SIGMA programme of support for the development of public administration and management (1992) establishes that most areas of the state are covered or affected by the so-called "acquis communautaire" (i.e. the totality of all European Union regulations).

In the European system of "acquis communautaire" there are no uniform requirements for public administration systems, but the countries of Europe have reached a common opinion on the common principles of public administration for all the states. This was done by combining the administrative law of the EU member States with the management practices of these States within the EU.

The Acquis communautaire does not have standards for horizontal systems of governance or national public administration, but rather for the principles of the rule of law, such as reliability, predictability, accountability and transparency, as well as technical and managerial competence, organizational capacity and citizen participation.

With this consensus, the principles of public administration adopted by the EU member States with different 
legal traditions and different systems of governance were created. Over time, these principles have been defined and updated through the jurisprudence of national courts and subsequently through the jurisprudence of the European Court of justice.

The General principles of public administration of the EU member States make up the "European administrative area" (EAP ), which includes a set of common standards for action within the public administration.

The principles of public administration "in the narrow sense" refer to a set of principles of European administrative law and the European administrative space, which arose in the process of convergence of regulation of public relations in the European Community with a single position. In a broad sense, the principles of public administration may include the above principles and principles of the law of the European Union, certain statutory principles of European organizations (Council of Europe (hereinafter - CE), EU, etc.), principles of international law, as well as the principles of the activities of the bodies, institutions and organizations of the EU with administrative directions [2, p. 18].

The basic principles of public administration include, as a rule, the rule of law, reliability, legal certainty, accountability and transparency, as well as sufficient organizational capacity and involvement of citizens in governance. Other important principles follow from these basic principles: decentralization, deconcentration, subsidiarity.

On the basis of democratic values and the rule of law at the end of XX beginning XXI century as the develop- ment of the European administrative space the concepts of good governance and good administration began to develop. It should be noted that the term "good administration", depending on the context, can mean both "good governance" and "good administration".

The concept of "good administration" is the ideology of "latinoamericanos" as opposed to "derivations" based on the European traditions of administrative law. That is why one of the basic standards of good governance is respect for the rights of individuals in the provision of administrative services.

In addition to the legal acts of the EU, "aquis communautaire" also includes acts that have no binding force, such as "white papers", "green papers", "guidelines". The White paper of the European governance sets out the principles of European governance and laid the Foundation for building the EAP. The ideas of the first White paper were later developed and supplemented by a number of White papers of the European Commission under the title "European governance", in particular the White paper from the European governance: assessment and transparency; the Author notes that together these documents set out the concept of European governance, formulated by the European Commission at the beginning of the XXI century, reveal its essence and components; explain how to increase citizens' commitment to the European Union for greater openness, transparency, public involvement in decision-making [4].

The 2006 Green paper (3 May 2006) is equally important for the formal definition of the principle of transparency is which refers to public consultations 
on three topics aimed at improving the transparency of decision-making procedures: the need for a more transparent framework governing the activities of state representatives, the need for feedback and mandatory disclosure of information about the beneficiaries of EU funds [5].

According to the Public Affairs Commission, there are currently about 15,000 lobbyists in the EU (consultants, lawyers, trade associations, corporations) who seek to influence EU officials and members of the European Parliament in Brussels. In the speech at the University of Nottingham on 3 March 2005, the Commissioner for administration And anti-fraud, Siim Callas, put forward the idea of the transparency initiative in three key areas:

- improving the financial reporting of EU funds;

- strengthening the personal integrity and independence of EU institutions;

- introduction of stricter control over lobbying.

In addition, the European Commission has created a web portal "Transparency", which consolidated the following essential provision: "The activities of the European Union today affect the lives of millions of European citizens. Decisions affecting them should be made as openly as possible. As a European citizen, you have the right to know how European institutions prepare these decisions, who takes part in their preparation, who receives funding from the EU budget, and what documents are prepared for the adoption of legal acts".

The term "Good Governance "is also widely used in international sci- entific literature to refer to" management processes carried out by public institutions for the management of public affairs and public resources in the context of the realization of human rights". In the modern Western sense, this term appeared not so long ago, after the Cold war era. The idea of building a fundamentally new management model under the term "Governance" appeared in Western science in the 90-ies. In this initial phase it was about a specific methodology regarding the basis of transition of the former colonies or countries with totalitarian regimes to democracy [7, p. 12].

The consolidation of the formation of "Governance" as a separate management model occurred after the publication in 1997 of the UN development Program "Governance" for the sustainable development of human resources.

As a dynamic concept, it has recently become widespread. Good governance means caring for the well-being of society and includes accountability, transparency, participation, openness and the power of law. Based on the study of the UN development Program "Governance" we can conclude that good governance means management of sustainable development, which is associated with such fundamental indicators of development:

1. Public participation in political life.

2. Transparency. This principle means that decisions are made and implemented in a manner consistent with established rules and regulations, and information is freely available to those who may be affected by decisions and their implementation. 
3. Sensitivity. Good governance requires that institutions and processes try to serve all stakeholders within a reasonable time frame and refers to the concept of a combination of response and ability.

4. Consensus orientation. Good governance requires consideration of different interests in order to achieve a broad consensus in a society that is of the greatest interest.

5. Equality and inclusion. The wellbeing of society depends on the assertion that all its members feel part of the whole and do not feel excluded from the path of its development.

6. Efficiency and effectiveness. Good governance means that all processes and institutions produce results that are relevant to the needs of society for the best use of resources.

7. Accountability. This is a key requirement for good governance. Not only state institutions, but also the private sector and public organizations should be accountable to society.

The latest report "on the development of mankind" in 2012, prepared by the UN Development Program [8], identified several reasons for the establishment of good governance. From the point of view of human development, good governance is identical to democratic governance, which means: respect for human rights and fundamental freedoms, giving citizens the right to live in dignity; recognition that people can make decisions that must be taken into account; recognition of the existence of private and public spheres of life and decision-making.

The above-mentioned provisions are examples of the significant attention, which is paid to the level of the
European Union to the principle of transparency of different public institutions.

As to the European principles of administrative law, they were defined in 1988 in the work of Yurgen Schwarz, "European administrative law" ("Europaisches Verwaltungsrecht"). The list includes: the principle of legality, the principle of non-discrimination, the principle of abolishment of the illegal administrative act, the principle of legal certainty, the right to protection, the principle of proportionality, the principle of respect for the fundamental rights of man and citizen, the principle of subsidiarity, the principle of good governance, the principle of transparency, the principle of application. It is on their basis formed the modern principles of the European Administrative space.

Based on the above, we can summarize the following. The EAP principles include the following groups: 1) legal certainty (reliability and predictability); 2) openness and transparency; 3) responsibility; 4) efficiency and effectiveness [9].

The group of principles "Openness and transparency" should include: the principle of openness as opposed to secrecy; the principle of transparency as opposed to discreteness; the principle of exclusivity of the confidential and secret nature of the activities of public authorities; the principle of entry into force only after official publication; the principle of subordination of public administrations to external control; the principle of mandatory justification and bringing the grounds for the decision to a person whose rights or legitimate interests are affected in 
connection with its adoption, and the like.

The principle of transparency as one of the modern principles of the EAP and European administrative law developed under the influence of Scandinavian principles of Good Governance. It was borrowed in the mid-90s of the twentieth century with the accession of Sweden and Finland to the EU. In European law, it is primarily concerned with access to official documents.

What should we understand under the "principle" of transparency? Where did it come from? And what is the function? What does the principle of transparency and the state of European law on access to public information mean? These are the questions that we will discuss next.

Article 11 of the Maastricht Treaty provides for the following provision:

"the institutions maintain an open, transparent and regular dialogue with representative associations and civil society. In order to ensure consistency and transparency of actions in the EU, the European Commission conducts extensive consultations with stakeholders". Despite the fact that this provision was purely declarative, but the fact of its consolidation at the level of the fundamental normative act of the EU was a decisive moment, which made it clear that the EU support from citizens is really relevant at any stage of the EU development.

The Treaty of Amsterdam was signed on 2 October 1997 (it entered into force on 1 May 1999). The Treaty of Amsterdam amended and supplemented the Maastricht Treaty on European Union, the Treaty of Rome establishing the European (Economic)
Community and European Atomic Energy Council, and the Treaty establishing the ECSC. The aim of the Amsterdam Treaty was to prepare the EU for expansion to the East and other global processes. The Amsterdam Treaty establishes the principles of EU "transparency" and "openness", according to which decisions within the EU should be made as openly as possible and be close to EU citizens. The principles of respect for human rights, democracy and the rule of law (the content of which includes the principle of transparency), on which the EU is based, and compliance with which is a condition for entry into it, are proclaimed.

The Treaty of Nice on amendments and additions to the Treaty on the European Union in 2001 set out certain recommendations to improve public access to public information, which are consolidated in the separate section "Transparency of the decision-making process". At that time, transparency in management is seen as one of the means to strengthen the "democratic nature of EU institutions and public confidence in management".

The concept of transparency has also become a key concept at the crisis stage of the EU development. Lakeny Declaration signed by the heads of the 15 member States of the EU showed that the EU is at "a crossroads", which at the same time is "a decisive step" of his existence, the principle of transparency has gained an important place in Lakeny Declaration [10] and is one of its most important issues. It is obvious that transparency is seen as a Central requirement of legitimate governance in the EU, in particular, "openness" and "transparency" are the key provi- 
sions of the report to the EU citizens by public institutions.

In this context, the definition provided by Attorney General R. J. Kolomer - in the case C-110/03 (Belgium v. Commission) can be considered as a source for the formulation of the characteristic features of this concept. According to transparency reflects the clarity, obvious and understandable without doubt or ambiguity.

However, the exact meaning of transparency depends on the context in which it is used and the function it performs. For example, in the GATT/ WTO, transparency is used as a measure of the openness and predictability of trade policies and the practices and processes that define them.

The EU's desire for openness and access to information by its citizens is also reflected in the 2004 EU Constitution Agreement. In this act, the concept of transparency is revealed through the prism of one of the fundamental rights of EU citizens to "good governance" (which we mentioned above) and access to public information. In this regard, we would like to note the rather rapid Constitution of the principles of "openness" and "public access to information" as prerequisites for the further development of the concept of transparency in the EU.

The analysis of the above-mentioned provisions of regulatory acts shows that transparency acts as a standard that acts as a measure of the legitimacy of the implementation of management measures, policies and law. Transparency contributes to the realization of the same values as the principle of legality, as a fundamental requirement of the legal basis of the government's actions. That is why the principle of transparency plays an important role in the field of law and policy-making in the EU.

In European Union law (hereinafter - EU), the concept of transparency is applied in a wide range of sectors, ranging from the basic principles of $\mathrm{EU}$ institutional law with the right of access to information and openness in the activities of EU institutions and bodies to a wide range of economic and financial legislation.

Thus, a number of specialized international legal instruments of a universal and regional character are also devoted to the concept of transparency. Among them: the Aarhus Convention of the United Nations Economic Commission for Europe on access to information, public participation in decision-making and access to justice in environmental matters, signed on 25 June 1998; Council of Europe Convention on access to official documents of 18 June 2009 p.; Code of good practice on public finance transparency developed by the International monetary Fund; Good practices of budget transparency, the Organization for economic cooperation and development, UNCITRAL Rules on transparency in the context of arbitrations between investors and States on the basis of international treaties 2014

Despite the specialized international legal agreements, still characterizing the formation of the concept of transparency in EU law, it should be emphasized that initially this concept arose in the areas related to the classical decision - making, which was manifested, in particular, in the introduction of the principle of openness of the decision- 
making process by the EU institutions and especially-citizens' access to information.

According to D. Dontsov, due to its history, mentality, tradition, ideology, Ukraine belongs to Europe and therefore in the conflict between Europe and Russia it is on the side of Europe. The reason for this conflict is Russia's rejection of the fundamental principles of the functioning of European society in the political, cultural, social, religious and economic spheres. These principles in politics include "logic and a precisely defined procedure, the institution of parliamentarism, the principle of the majority and mutual assurance in politics" [11].

In the early 20-ies of XX century, D. Dontsov, put forward the slogan of "Westernization", which he understood as "nurturing all living in the people's psyche traditions and institutions of the West". He underlined the importance of democratic institutions of Western society for the formation of the internal policy of the state: local self-government, not state intervention in the economy, ensuring the rights and freedoms of citizens.

Summary. Thus, reflecting the latest achievements of international legal regulation and including a number of innovative aspects, transparency provisions occupy a special place in the legal system of the European Union. At the level of international legal agreements, special mechanisms are created to ensure the predictability of changes in the political regimes of the EU member States.

Ukraine's conclusion of the Association Agreement with the EU makes it possible to predict that the imple- mentation of its transparency concept will have an extraordinary impact on the legal system of Ukraine. Of course, Ukraine's implementation of these obligations will allow citizens to benefit from a transparent and prospective legislative field. On the other hand, it will require a substantial reform of regulatory policy, improving the institutional and organizational capacity of public authorities involved in the preparation and adoption of the activities covered by the Agreement.

\section{REFERENCES}

1. The European Administrative Space: Governance in Diversity. (2002). Annual Conference of the European Group of Public Administration (EGPA), September 2002, the University of Potsdam, BRD. wrere.unipotsdam.de. Retrieved from http:// www.uni-potsdam.de/egpa2002 [in English].

2. Averianov V. B. (Eds.). (2007). Derzhavne upravlinnia: yevropeiski standarty, dosvid ta administratyone pravo [Public administration: European standards, experience and administrative law]. Kyiv: Yustinian [in Ukrainian].

3. Yevropeiski pryntsypy derzhavnoho upravlinnia [European Principles of Public Administration]. (2000). (O. Yu. Kulenkova, Trans). Kyiv: UADU [in Ukrainian].

4. European Transparency Initiative. Green Paper. (n.d.). ec.europa.eu. Retrieved from http://ec.europa.eu/ comm/eti/docs/gp_en.pdf [in English].

5. Green Paper on the Review of the Consumer Acquis Paper. (n.d.). wrere. europarl.europa.eu. Retrieved from http://www.europarl.europa.eu / meetdocs/2004_2009/documents/ 
com/com_com(2006)0744_/com com(2006)0744_en.pdf [in English].

6. Novak-Kaliaieva L. M. (2013). Suchasni tendentsii do konverhentsii v kontseptsiiakh derzhavnoho upravlinnia [Contemporary trends in convergence in the concepts of state administration]. Visn. Nats. akademii derzh. upr. pry Prezydentovi Ukrainy Bulletin of the National Academy of Public Administration under the President of Ukraine, 1, 29-41 [in Ukrainian].

7. Korzhenko V. V., Khashyieva L. V. (2011). Stanovlennia kontseptsii Governance $\mathrm{u}$ protsesi formuvannia suchasnoho yevropeiskoho administratyvnoho prostoru [Formation of the concept of Governance in the process of forming a modern European administrative space]. Visn. Nats. akademii derzh. upr. pry Prezydentovi Ukrainy Bulletin of the National Academy of Public Administration under the President of Ukraine, 2, 10-19 [in Ukrainian].

8. Human Development Report 2012: Deeping democracy in a fragmented world. (2012). United Nations Development Programme (UNDP). New York: Oxford University Press. Retrieved from http://hdr.undp. org/sites/default/files/reports/263/ hdr_2012_en_complete.pdf [in English].

9. Mapping European Union Administrative Law. wrorobanet.org. Retrieved from http://www.abanet.org [in English].

10. Laeken Declaration on the future of the European Union (15 December 2001). wrow.cvсе.eu. Retrieved from https://www.cvce.eu/content/publication/2002/9/26/a76801d5-4bf04483-9000-e6df94b07a55/publishable_en.pdf [in English].

11. Dontsov D. (1921). Pidstavy nashoi polityky [The Foundations of Our
Politics]. Viden: Vyd-vo Dontsovykh. Retrieved from https://www.myslenedrevo.com.ua/uk/Publ/Dontsov/ BasesOurPolicy.html [in Ukrainian].

\section{СПИСОК ВИКОРИСТАНИХ ДЖЕРЕЛ}

1. The European Administrative Space: Governance in Diversity // Annual Conference of the European Group of Public Administration (EGPA), September 2002, the University of Potsdam, BRD [Електронний peсурс]. Режим доступу: http://www. uni-potsdam.de/egpa2002

2. Державне управління: європейські стандарти, досвід та адміністративне право / за заг. ред. В. Б. Аверьянова. К. : Юстініан, 2007. 287 с.

3. Свропейські принципи державного управління / пер. з англ. О. Ю. Куленкової. К. : УАДУ, 2000. 184 с.

4. European Transparency Initiative. Green Paper [Електронний ресурс]. Режим доступу: http://ec.europa.eu/ comm/eti/docs/gp_en.pdf

5. Green Paper on the Review of the Consumer Acquis Paper [Електронний ресурс]. Режим доступу: http://www.europarl.europa.eu/ meetdocs/2004_2009/documents/ com/com_com(2006)0744_/com com(2006)0744_en.pdf

6. Новак-Каляєва Л. М. Сучасні тенденції до конвергенції в концепціях державного управління // Вісн. Нац. академіі держ. упр. при Президентові України. 2013. № 1. C. 29-41.

7. Корженко В. В. Становлення концепції Governance у процесі формування сучасного європейського адміністративного простору / В. В. Корженко, Л. В. Хашиєва // Вісн. Нац. Академії держ. упр. при Президентові України. 2011. № 2. C. 10-19. 
8. Human Development Report 2012: Deeping democracy in a fragmented world // United Nations Development Programme (UNDP). - N.-Y.: Oxford University Press. 2012 [Електронний pecypc]. Режим доступу: http:// hdr.undp.org/sites/default/files/reports/263/hdr_2012_en_complete.pdf

9. Mapping European Union Administrative Law [Електронний ресурс]. Режим доступу: www.abanet.org

10. Bulletin of the European Union. 2001, № 12. Luxembourg: Office for Official Publications of the
European Communities. "Presidency Conclusions of the Laeken European Council (14 and 15 December 2001)", p. 19-23. [Електронний ресурс]. Режим доступу: https://www.cvce. $\mathrm{eu} /$ content/publication/2002/9/26/ a $76801 \mathrm{~d} 5$ - $4 \mathrm{~b}$ f $0-4483-9000$ e6df94b07a55/publishable_en.pdf

11. Донщов Д. Підстави нашої політики. Відень : Вид-во Донцових, 1921. 212 с. [Електронний ресурс]. Режим доступу: https://www.myslenedrevo. com.ua/uk/Publ/Dontsov/ BasesOurPolicy.html 